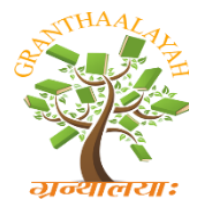

\author{
INTERNATIONAL JOURNAL OF RESEARCH - \\ GRANTHAALAYAH \\ A knowledge Repository
}

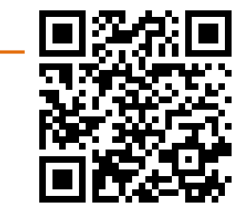

Science

\title{
CHARASTERISTICS OF CURCAS BEAN BIODIESEL AFTER CATALYTIC CRACKING WITH H-ZEOLITE CATALYST
}

\author{
Julianus Dising 1 , Laurensius Lehar *1 \\ ${ }^{1}$ Department Food Crops and Horticulture, State Agricultural Polytechnic of Kupang, Indonesia
}

\begin{abstract}
The development of curcas bean (Jatropha curcas Linn) as a raw material for biodiesel have a very promising potential, because in addition to producing oil with high productivity (40-45\%). Curcas bean oil was transesterified at $60 \mathrm{oC}$ for 120 minutes to produce biodiesel. The produced biodiesel was the cracked with the H-zeolite catalyst at $70^{\circ} \mathrm{C}, 80^{\circ} \mathrm{C}, 90^{\circ} \mathrm{C}, 100^{\circ} \mathrm{C}, 110^{\circ} \mathrm{C}$, and $120^{\circ} \mathrm{C}$ for 60 , 90, and 120 minutes. This study was aimed to characterize the curcas bean biodiesel that had been cracked using $\mathrm{H}$-zeolite catalyst. Characterization of the biodiesel from cracking process included viscosity, saponification number, iodine number, and cetane number. Results of the study indicated that the breakdown of carbon chain in the fatty acid of curcas bean biodiesel can be achieved by catalytic cracking. This was evidenced by the reduced viscosity and iodine number and increased saponification number and cetane number of the curcas bean biodiesel after cracking. Analysis of the curcas bean biodiesel product obtained indicated that the optimum temperature was $90^{\circ} \mathrm{C}$ and optimum reaction time was 180 minutes. Characteristics of the curcas bean biodiesel on these conditions included the viscosity of $3.850 \mathrm{cSt}$, saponification number of $206.332 \mathrm{mg} \mathrm{KOH} / \mathrm{g}$ sample, iodine number of $60.11 \mathrm{mg}$ Iodine/g sample, and cetane number of 68.83. GCMS test on the biodiesel composition indicated the presence of $0.798 \%$ of methyl laurate $\left(\mathrm{C}_{13} \mathrm{H}_{26} \mathrm{O}_{2}\right), 44.527 \%$ of methyl palmitate $\left(\mathrm{C}_{17} \mathrm{H}_{34} \mathrm{O}_{2}\right), 4.584 \%$ of methyl linoleic $\left(\mathrm{C}_{19} \mathrm{H}_{34} \mathrm{O}_{2}\right), 46.506 \%$ of methyl oleic $\left(\mathrm{C}_{19} \mathrm{H}_{36} \mathrm{O}_{2}\right)$ and $3.584 \%$ of methyl stearic $\left(\mathrm{C}_{19} \mathrm{H}_{36} \mathrm{O}_{2}\right)$.
\end{abstract}

Keywords: Fatty Acid; Curcas Bean; Biodiesel; Cracking; Zeolite.

Cite This Article: Julianus Dising, and Laurensius Lehar. (2019). "CHARASTERISTICS OF CURCAS BEAN BIODIESEL AFTER CATALYTIC CRACKING WITH H-ZEOLITE CATALYST." International Journal of Research - Granthaalayah, 7(8), 367-373. https://doi.org/10.29121/granthaalayah.v7.i8.2019.685.

\section{Introduction}

The development of curcas bean (Jatropha curcas Linn) as a raw material for biodiesel have a very promising potential, because in addition to producing oil with high productivity, this plant also has a low economical value as non-food plant, and capable of producing plenty of fruits all the year. Curcas beans have a relatively high oil content, about $40-45 \%$ of its weight contain about $77.3 \%$ of unsaturated fatty acid and $22.7 \%$ of saturated fatty acid (Dising, 2007). 
Gubitz in Zhang, et. al (2008) suggested that curcas bean oil contained fatty acids with carbon chain length ranging from $\mathrm{C}_{16}-\mathrm{C}_{18}$. Lubis (2007) stated that the longer the carbon chain, the higher the viscosity of the fuel. The high viscosity of a fuel makes it difficult to inject into ignition chamber in diesel engine. The viscosity of curcas bean biodiesel ranges from 8.55-10.82 cSt (Dising, 2007), 14.159 cSt (Purba, 2007), to 11.44 cSt (Wisyastuti, 2007).

The high unsaturated fatty acids content, oleic and linoleic (60-90\%), in the curcas bean oil makes the cetane number of its biodiesel is low, only about 54.28 (Dising, et.al, 2012). According to Purba (2007), cetane number of biodiesel produced from transesterification was 54.32. Knothe et. al. (2003) suggested that the increased double bond can reduce cetane number. The high cetane number is observed in saturated fatty acid esters such as palmitate and stearic acid. Generally, the cetane number of monounsaturated fatty acid like oleic have been reported in the intermediate range.

This study was aimed to characterize the curcas bean biodiesel that had been cracked using $\mathrm{H}$ zeolite catalyst. Characterization of the biodiesel from cracking process included viscosity, saponification number, iodine number, and cetane number.

\section{Material and Method}

Material using in this research is curcas bean oil, methanol, $\mathrm{NaOH}$, alcohol, pp indicator, distilled water, chloride acid $(\mathrm{HCl})$, chloroform $\left(\mathrm{CHCl}_{3}\right)$, KI, sodium thiosulphate $\left(\mathrm{Na}_{2} \mathrm{~S}_{2} \mathrm{O}_{3}\right)$, starch indicator, and H-zeolite catalyst. Synthesis of H-Zeolite catalyst using the Plank method (Plank, 1990).

Method of research is curcas bean oil was transesterified at $60^{\circ} \mathrm{C}$ for 120 minutes to produce biodiesel. The produced biodiesel was the cracked with the $\mathrm{H}$-zeolite catalyst at $70^{\circ} \mathrm{C}, 80^{\circ} \mathrm{C}, 90^{\circ} \mathrm{C}$, $100^{\circ} \mathrm{C}, 110^{\circ} \mathrm{C}$, and $120^{\circ} \mathrm{C}$ for 60,90 , and 120 minutes. The biodiesel product was then quantitatively tested. The test included the viscosity, saponification number, iodine number, and cetane number. GCMS was used to determine the composition of the curcas bean biodiesel.

\section{Results and Discussion}

In this research will show the characteristics of curcas bean biodiesel after cracking reaction. Curcas bean biodiesel characteristics include viscosity, saponification number, iodine value and cetane number will be described hereinafter. Biodiesel derived from curcas bean oil transesterification reaction, cracking at temperatures $70,80,90,100,110$, and $120^{\circ} \mathrm{C}$ at reaction times of 60,120 , and 180 minutes.

\section{Viscosity of Curcas Bean Biodiesel}

Figure 1 shows the relationship between temperature and reaction time cracking the viscosity of biodiesel. The longer the reaction time and the higher the reaction temperature, the lower the viscosity of the produced biodiesel. For the reaction time of 180 minutes and temperature reaction of $70,80,90,100,110$, and $120^{\circ} \mathrm{C}$, the viscosity obtained were $4.15 \mathrm{cSt}, 4.390 \mathrm{cSt}, 3.850 \mathrm{cSt}$, $3.493 \mathrm{cSt}, 3.519 \mathrm{cSt}$, and $3.509 \mathrm{cSt}$. It can be seen from these data that the reduction of biodiesel viscosity was caused by the breakdown of carbon chains composing the curcas bean biodiesel. 
This is in accordance with Lubis (2007) and Dising (2007) that the viscosity of a fuel was highly influenced by the length of the carbon chains constructing the fuel. The longer the carbon chain, the higher the viscosity. Conversely, the shorter the carbon chain, the lower the viscosity. GCMS analysis indicated the increase of methyl palmitate $\left(\mathrm{C}_{17} \mathrm{H}_{34} \mathrm{O}_{2}\right)$ and reduction of methyl oleic $\left(\mathrm{C}_{19} \mathrm{H}_{36} \mathrm{O}_{2}\right)$ and methyl linoleic $\left(\mathrm{C}_{19} \mathrm{H}_{34} \mathrm{O}_{2}\right)$ level. The increase methyl palmitate level after catalytic cracking reaction again proved the breaking of carbon chain in curcas bean biodiesel.

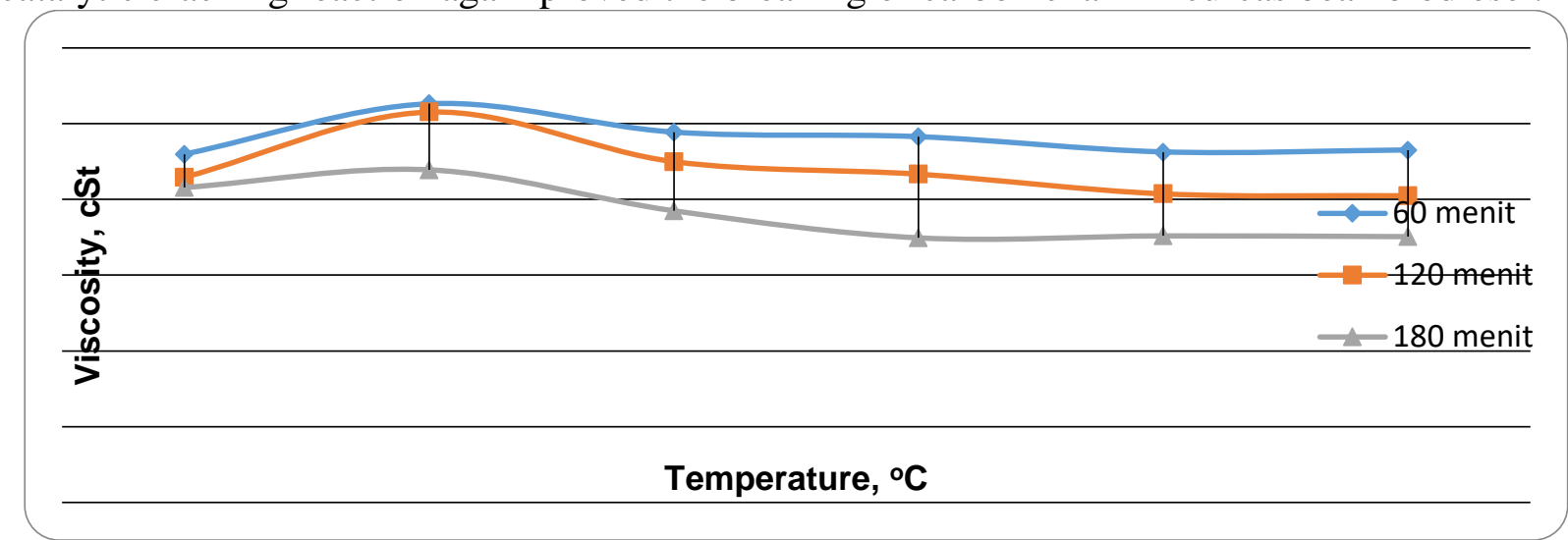

Figure 1: The influence of cracking reaction temperature and time on the viscosity of curcas bean biodiesel

\section{Saponification Number of Curcas Bean Biodiesel}

Figure 2 shows the relationship between temperature and reaction time cracking the saponification number of biodiesel. The highest saponification number is achieved at $90^{\circ} \mathrm{C}$ and 180 minutes. At these conditions, the saponification number obtained was $206.332 \mathrm{mg} \mathrm{KOH} / \mathrm{g}$ sample. These data indicated that the reaction temperature at $90^{\circ} \mathrm{C}$ and reaction time of 180 minutes were the optimum conditions for the breaking of carbon chains of the curcas bean biodiesel. The high saponification number (206.332 $\mathrm{mg} \mathrm{KOH} / \mathrm{g}$ sample) indicated that the compounds composing the curcas bean biodiesel contained fatty acids with relatively low molecular weight. When the molecular weight is low, the mole of the biodiesel will increase, thus it needs many $\mathrm{KOH}$ for saponification (Widyastuti, 2007). According to these data, it can be assumed that a cracking reaction had occurred that breakdown the carbon chain of unsaturated fatty acid ester, oleic or linoleic, in the curcas bean biodiesel. The carbon chain breaking occurred in the saturated fatty acid ester will form new fatty acid esters with carbon chain length of $\mathrm{C}_{12}-\mathrm{C}_{16}$. This was confirmed by GCMS analysis which indicated a significant increase in methyl palmitate level.

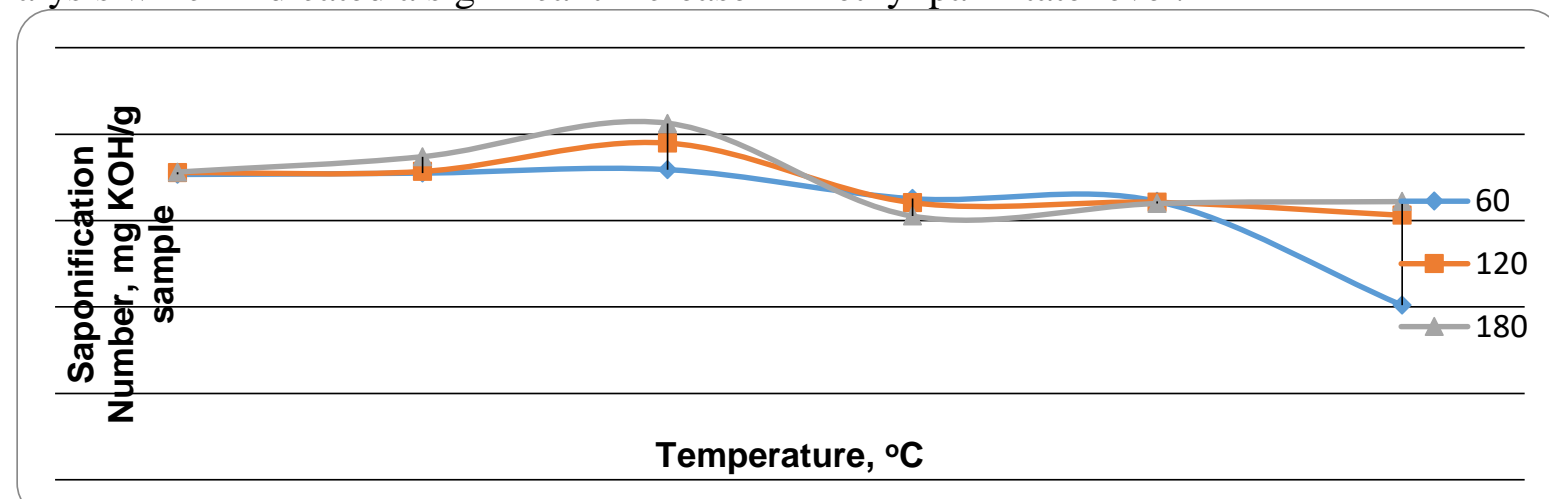

Figure 2: The influence of cracking reaction temperature and time on saponification number of curcas bean biodiesel 


\section{Iodine Number of Curcas Bean Biodiesel}

Figure 3 shows the relationship between temperature and reaction time cracking the iodine number of biodiesel. Iodine number of biodiesel indicates the unsaturation level compounds composing it. Iodine number of the curcas bean biodiesel from transesterification reaction was $92.38 \mathrm{mg}$ iodine/g sample. This value meets the SNI 04-7182-2006 standard that requires $115 \mathrm{mg}$ iodine/g sample as maximum iodine number for biodiesel. However, the iodine number of $92.38 \mathrm{mg}$ iodine/g sample was near the maximum threshold. From these data it can be estimated that the curcas bean biodiesel still contain high unsaturated fatty acid ester. The obtained iodine number of the curcas bean biodiesel after catalytic cracking reaction, shows the presence of iodine number decrease to 60.11 mg iodine/g sample at reaction temperature of $90^{\circ} \mathrm{C}$ and reaction time of 180 minutes.

The decrease in iodine number of the curcas bean biodiesel after catalytic cracking reaction indicated that the produced biodiesel was more saturated, suggesting that the carbon chain breakdown reaction had occurred, thus the saturating in its double bonds. This was confirmed by GCMS analysis, as shown in Table 1. This table shows the saturated fatty acid ester is $45.326 \%$ and unsaturated fatty acid ester is $54.674 \%$.

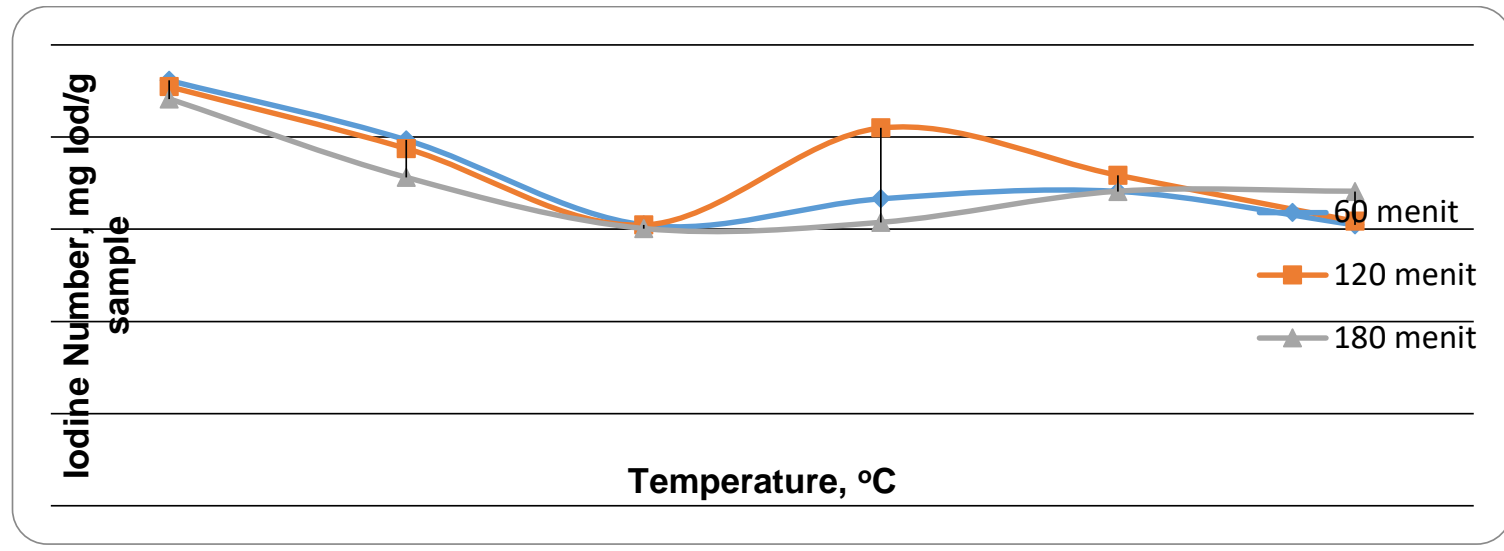

Figure 3: The influence of cracking reaction temperature and time on iodine number of curcas bean biodiesel

Figure 4 shows the relationship between temperature and reaction time cracking cetane number of biodiesel. Cetane number is a parameter to determine the quality of biodiesel. Study results indicated that the highest cetane number (68.83) was obtained at reaction temperature of $90^{\circ} \mathrm{C}$ and reaction time of 180 minutes. This number was higher when compared to that of before cracking (54.28). This indicated the increase of cetane number after catalytic cracking reaction by 14.55 . This cetane number was much higher than the standard required by Indonesian biodiesel quality standar (SNI) minimum cetane number is 51 (Badan Standar Nasional, 2006).

According to Shreve in Knothe, et.al (2006), the high cetane number will cause the fuel ignites in a relatively low temperature with rapid ignition time. Thus, the quality of the biodiesel produced in this study will increase with the cetane number. The low cetane number before cracking was due to the presence of unsaturated fatty acids such as oleic and linoleic in the composition of the curcas bean diesel. The cetane number was increased significantly about $30 \%$ after catalytic cracking. 
According to Knothe et. al (2003), the increased double bond can cause lower the cetane number but, generally, the higher cetane number for saturated fatty acid ester. Therefore, reducing the unsaturated fatty acid ester level in the curcas bean biodiesel composition by up to $88.044 \%$ after cracking will automatically increase the cetane number of the curcas bean biodiesel. This indicated that after catalytic cracking there was a decrease in unsaturated fatty acid ester by about $37.902 \%$.

Knothe (2008) also suggested the cetane number of some straight-chain fatty acid methyl esters such as methyl laurate (66.70), methyl palmitate (85.9), methyl stearic (101), methyl oleic (59.3) and methyl linoleic (38.2). This confirmed the finding of this study. According to GCMS analysis, it can be concluded that the increased cetane number after catalytic cracking reaction was caused by the increased methyl palmitate and methyl stearic in the composition of curcas bean biodiesel.

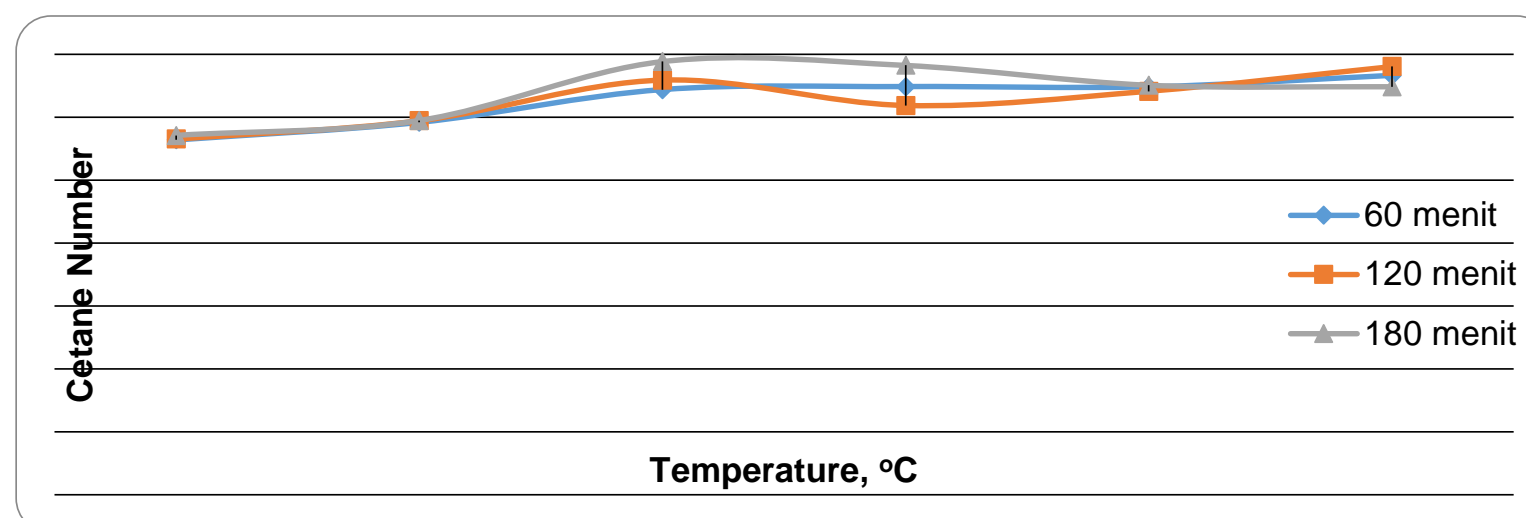

Figure 4: The influence of hydrocracking reaction temperature and time on cetane number of curcas bean biodiesel

\section{Composition of Curcas Bean Biodiesel}

Based on viscosity, the number of the bribe, the number of iodine, and the number of stampspacing biodiesel after the directive is obtained the best reaction conditions are at the temperature of $90 \mathrm{oC}$ and the reaction Watu 180 minutes. In this case, the GCMS analysis is carried out to obtain a plants composition of curcas bean biodiesel. Composition of curcas bean biodiesel after cracking by GCMS analysis as shown in Table 1. In table 1, obtained methyl lauric $0.798 \%$, methyl palmitate $44.527 \%$, methyl linoleate $4.584 \%$, methyl oleic $46.506 \%$, and methyl stearate $3.584 \%$. This data indicates that the curcas bean biodiesel obtained through the cracking reaction contains $48.910 \%$ methyl ester of saturated fatty acids and $51.090 \%$ methyl ester of unsaturated fatty acids.

Table 1: Composition of Fatty Acid Methyl Esters of Curcas Bean Biodiesel after Cracking at $90^{\circ} \mathrm{C}$ for 180 minutes.

\begin{tabular}{|l|l|l|l|}
\hline Fatty Acid Methyl Ester & Retention Time & Corrected Peak Area & Composition (\%) \\
\hline Methyl laurate & 17.590 & 1023224 & 0.798 \\
\hline Methyl palmitate & 19.338 & 57083817 & 44.527 \\
\hline Methyl linoleic & 20.951 & 5877228 & 4.584 \\
\hline Methyl oleic & 21.002 & 59620625 & 46.506 \\
\hline Methyl stearic & 21.227 & 4595102 & 3.584 \\
\hline
\end{tabular}




\section{Conclusions and Advice}

From the results of this study, some conclusions can be drawn the optimum temperature for the catalytic cracking reaction of curcas bean biodiesel was $90^{\circ} \mathrm{C}$ and the optimum time reaction was 180 minutes. The produced biodiesel at these conditions had viscosity of $3.580 \mathrm{cSt}$, saponitication number of $206.332 \mathrm{mg} \mathrm{KOH} / \mathrm{g}$ sample, iodine number of $60.11 \mathrm{mg}$ iodine/g sample, and cetane number of 68.83. GCMS analysis found the following compounds in the composition of curcas bean biodiesel: methyl lauric $\left(\mathrm{C}_{13} \mathrm{H}_{26} \mathrm{O}_{2}\right)(0.798 \%)$, methyl palmitate $\left(\mathrm{C}_{17} \mathrm{H}_{34} \mathrm{O}_{2}\right)$ (44.527\%), methyl linoleic $\left(\mathrm{C}_{19} \mathrm{H}_{34} \mathrm{O}_{2}\right)(4.584 \%)$, methyl oleic $\left(\mathrm{C}_{19} \mathrm{H}_{36} \mathrm{O}_{2}\right)(46.506 \%)$, and methyl stearic $\left(\mathrm{C}_{19} \mathrm{H}_{38} \mathrm{O}_{2}\right)(3.584 \%)$.

For further research needs to be studied further comparison with biodiesel catalyst, and the effect of reaction temperature and reaction time for the hydrocracking process with the same catalyst $(\mathrm{H}-$ zeolite).

\section{Conflict of Interest}

The authors declared that present study was performed in absence of any conflict of interest".

\section{Acknowlegement}

Thank you to friends who have helped during the research activities. The results of this study are dedicated to the development of science.

\section{Author Contributions}

JD design and conduct research, data collection, data analysis and also manuscript writing. LL designs and conducts research, reviewing manuscripts and submit manuscripts.

\section{References}

[1] Badan Standarisasi Nasional. (2006). Spesifikasi Biodiesel SNI 04-7182-2006

[2] Dising, J. (2007). Karakteristik Biodiesel dari Minyak Jarak Pagar dan Minyak Jelantah, Jurnal ADIWIDIA, Eidisi Juli, 2007, hal 11-22

[3] Dising, J., Jalaluddin, M.N., Sjahrul, M., Harlim, T.,. (2012). A Study of Catalytic Cracking in the Production of Super Cetane Biodiesel from Jatropha curcas Oil. International Journal, Research Journal of Science, 2012, Vol.1 (12), page 61-64.

[4] Knothe, G., Matheaus A.C., and Ryan Thomas W. (2003). Cetane numbers of branched and straight-chain fatty esters determined in ignation quality tester. Fuel 82 (2003) 971-975.

[5] Knothe, G., Sharp, C.A., and Ryan, T.W., (2006). "Exhaust Emissions of Biodiesel, Petrodiesel, Neat Methyl Esters, and Alkanes in a New Technology Engine”, Energy \& Fuel, Vol. 20 (1), page 403-408.

[6] Knothe, G. (2008), "Designer Biodiesel": Optimizing Fatty Ester Composition to Inprove Fuel Properties. Energy Fuels, 2008, Vol. 22 (2), page 1358-1364.

[7] Kusmiyati. (2008). Reaksi Katalisis Esterifikasi Asam Oleat dan Metanol Menjadi Biodiesel dengan Metode Distilasi Reaktif. Reaktor 2008, 2 (2) 78-82.

[8] Lubis, S. S. (2007). Studi Pencampuran Biodiesel Jarak Pagar Dengan Solar Terhadap Perubahan Karakteristik Fisiknya.. Program Studi Ilmu Fisika, Universitas Sumatera Utara. 
[9] Plank, Charles J,. (1990). Methode for Producing Zeolite. United State Patent4,341,748, 1990.

[10] Purba, J.. (2007). Pembuatan dan Karakterisasi Metil Ester Asam Lemak Jarak Pagar yang Digunakan sebagai Biodiesel. Jurusan Kimia Universitas Sumatera Utara.

[11] Widyastuti, L,. (2007). Reaksi Transesterifikasi Minyak Biji Jarak Pagar menjadi Metil Ester sebagai Bahan Bakar Pengganti Minyak Diesel dengan menggunakan Katalis KOH. Jurusan Kumia FMIPA UNNES

[12] Zhang, J., Jiang, L. (2008). Acid-catalyzed esterification of Zanthoxylum bungeanum seed oil with high free fatty acids for biodiesel production. Bioresource Technology 99 (2008) 8995-8998.

*Corresponding author.

E-mail address: laurensiusl@ yahoo.co.id 